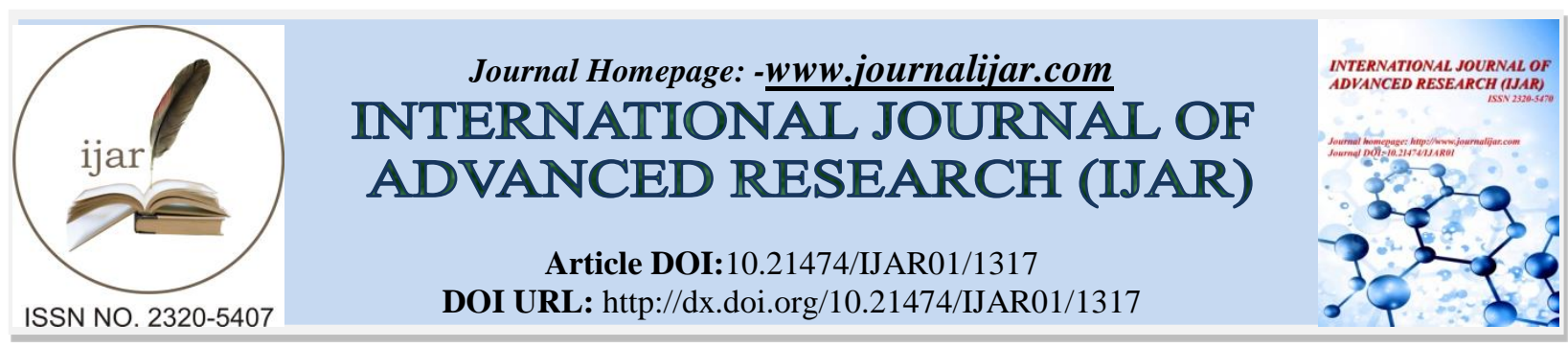

RESEARCH ARTICLE

\title{
MACRO AND MICROSCOPICAL STUDIES ON THE PINEAL GLAND OF CAMEL WITH IMMUNOHISTOCHEMICAL LOCALIZATION TO PINEALOCYTES AND GLIA CELLS MARKERS.
}

Rasha. R. Beheiry ${ }^{1}$ and Attia. A. A. Moselhy ${ }^{2}$.

1. Department of Histology and Cytology Faculty of Veterinary Medicine, Zagazig University. Egypt.

2. Department of Anatomy and Embryology, Faculty of Veterinary Medicine, Zagazig University. Egypt.

\section{Manuscript Info}

Manuscript History

Received: 12 June 2016

Final Accepted: 19 July 2016

Published: August 2016

Key words:-

Pineal gland, Anatomy, Histology,

Immunohistochemistry, Camel.

\section{Abstract}

This study was aimed to examine the anatomical, histological and immunohistochemical studies on the pineal gland of adult camel. Immunoperoxidase methods for the demonstration of synaptophysin and three glial antigens (vimentin, S-100 protein and glial fibrillary acidic protein).Ten pineal glands of adult camels were used in this study. The results revealed that the pineal gland of camel was light to dark brown and fusiform in shape. It was situated at the pineal recess caudal to the splenium of the corpus callosum and caudodorsal to the third ventricle and in front of the rostral colliculi. The pinealocytes and glia cells are the two types of parenchymal cells in addition to the presence of calcified concretions. The immunohistochemical findings showed that the synaptophysin immuno reactive cells were observed with strong reaction in the periphery of the gland. The synaptophysin immnoreactivity showed different degrees of density. The reaction was mainly observed in the perivascular spaces and the negative reaction was observed around the brain sand and in the interstitial cells. The positive reaction to vimentin immunoreactivity was distributed throughout the gland, in the capsule and septa of the gland, in the endothelial cells of blood vessels, around the brain sand and the perivascular spaces forming network. The strong positive reaction to S-100 protein was detected especially in the stalk and the proximal region of the gland that is denser than vimentin immunoreactivity. GFAP immunoreactive cells were mainly distributed in the proximal region of the gland and little reaction in the distal region.

Copy Right, IJAR, 2016,. All rights reserved.

\section{Introduction:-}

Camel is an important animal has ability to convert the scanty plant resources of the desert into milk and meat. Camel is a hardy animal, goes into sleep for short intervals and has a long lasting memory (Khan et al., 2003). The ability of camel to live and perform in the hard arid regions of the world has earned the name "Ship of the Desert" (Iqbal, 1999 and Khan et al., 2003). The researches about camel pineal gland were about its morphology and structure (Abbas and Ewais, 1982 and Nawal et al., 2012) and involution signs (Abou-Easa, et al., 2009). It contains two types of parenchymal cells. The pinealocytes are responsible for melatonin secretion in the pineal gland. Glial cells serve as supporting cells and they are fewer in number than pinealocytes (Arendt, 1995 and Kus 
et al., 2004). Melatonin is secreted in a daily rhythmic manner with a nocturnal peak (Shimizu et al., 2003). Brain sand or corpora arenacea was considered as one of the landmarks of the pineal tissue of mammals (Vigh et al., 1998 and Koshy and Vettivel, 2001). S100 belongs to a multifunctional subfamily of Ca2+-binding proteins that have many functions including motility, chemotaxis, and secretion (Heizmann et al., 2002). S-100 protein with two different types of intermediate filament proteins, (glial fibrillary acidic protein (GFAP) and vimentin, are known as glial marker proteins (Boya and Calvo, 1993). Synaptophysin is asynaptic vesicle glycoprotein with four transmembrane domains weighing $38 \mathrm{kDa}$. It is present in neuroendocrine cells and in all neurons in the brain and spinal cord that participate in synaptic transmission. (Calhoun et al., 1996). The goal of this research to study the morphology of pineal gland in camel and the arrangement of parenchymal cells by using antibodies for synaptophysin, as a marker of pinealocytes, and glial fibrillary acidic protein (GFAP), S100 and vimentin as markers of interstitial (glial) cells and if there are differences in the distribution of these antibodies throughout the gland.

\section{Materials and methods:-}

The specimens for the present work included ten heads of freshly slaughtered camels (Camelus dromedarius). The specimens were collected from Zagazig abattoir. The selected camels were in good general condition; their ages were ranged around three to seven years. Five heads were injected via the common carotid artery with $10 \%$ buffered neutral formalin solution for at least four weeks to be used in anatomical investigation. Nomenclature used in this study was adopted by Nomina Anatomica Veterinaria (2012). For histological observations, pineal glands were extracted from freshly slaughtered camels and then fixed in 10\% buffered neutral formalin, 5-6 microns thick sections were cut. The sections were stained with the following stains: 1) Harris's haematoxylin and Eosin for studying the general structures.2) Van Gieson and crossmons trichrome stain for collagen \& muscle fibers). 3) Periodic acid Schiff technique for neutral and some acidic mucopolysaccharides. The methods of processing and staining were adopted by (Bancroft and Gamble, 2001).

Tissue preparation for immunohistochemistry:

Immunohistochemical staining was carried out using the streptavidin-biotin complex technique (Polak and Noorden, 1997). (ABC) method was utilised for $5 \mu \mathrm{m}$ thick sections. All staining procedure was carried out according to manufacturer protocol of Thermo Scientific. Sections were deparaffinized in xylene and rehydrated through a graded series of ethanol. To reduce non specific back ground staining due to endogenous peroxidase, incubate slides in $\mathrm{H} 2 \mathrm{O} 2$ for 10 minutes then wash two times in phosphate-buffered saline (PBS; $\mathrm{pH} 7.4)$. Incubate slides in microwave EDTA $\left(\mathrm{pH} \mathrm{8)}\right.$ for $15-20$ minutes at $99^{\circ} \mathrm{c}$ then wash in tap water. Wash 4 times in buffer optional apply (Ultra V Block (normal serum), Thermo Fisher Scientific, LabVision Corporation, Fremont, CA), and incubate for 5 minutes at room temperature to block non specific back ground stain, don't exceed 10 minutes to or there may be reduction in result stain. Wash four times in PBS. Apply the primary antibody (GFAP Cataloge. No. monoclonal antibody AB1-Ms 280 R \& S100 Catalog.No. monoclonal antibody AB1-Ms 296 R7 and Vimentin Cataloge. No. AB2 mouse monoclonal antibody-MS $129 \mathrm{R} 7$ and synaptophysin Cataloge. No. rabbit monoclonal antibody RM 9111R7 Lab vision company) and incubate according to manufacture protocol then wash in PBS. Apply in biotinylated goat antipolyvalent and incubate for 10 minutes at room temperature then in PBS. Apply streptavidin peroxidase and incubate for 10 minutes at room temperature then rinse in PBS. Sections were counterstained with hematoxylin, dehydrated through an alcohol series, cleared in xylene, and mounted by using DPX.

\section{Results:-}

Anatomical observations:-The pineal glands of camel were light to dark brown and fusiform in shape. It was situated between the two cerebral hemispheres at the pineal recess caudal to the splenium of the corpus callosum and caudodorsal to the third ventricle and in front of the rostral colliculi Fig (1). 


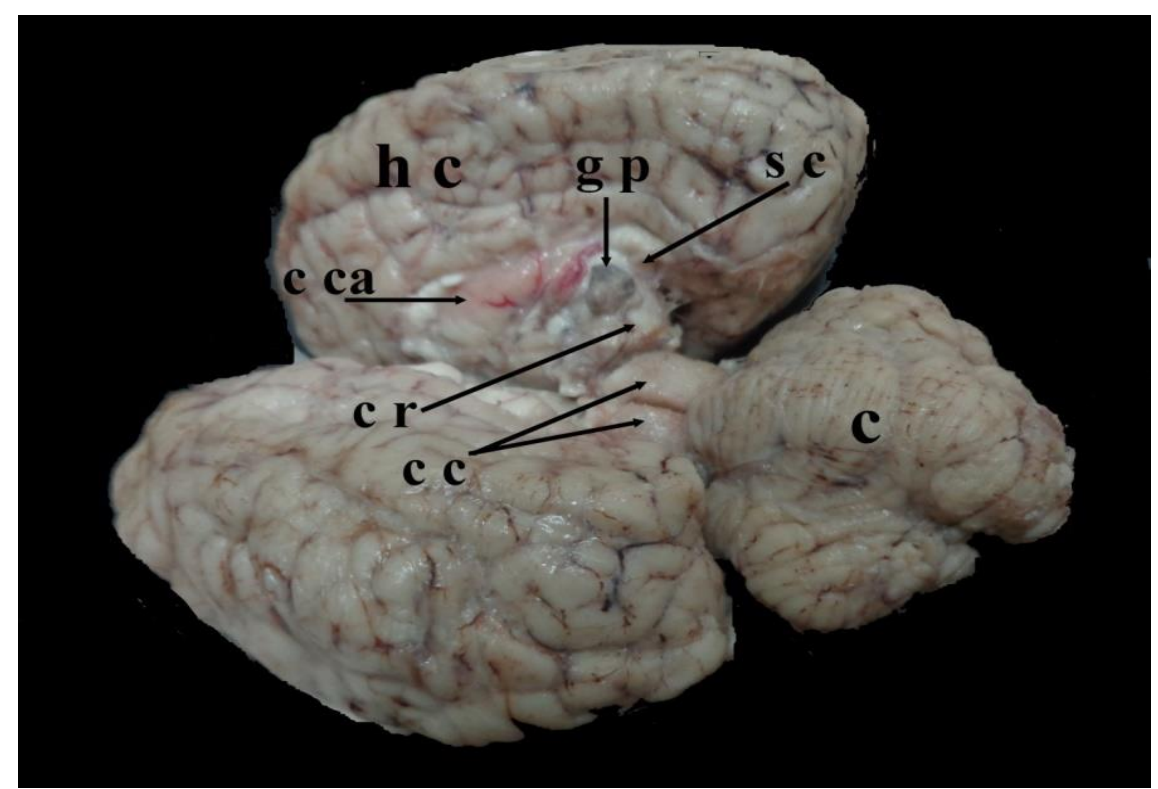

Fig 1:-.Photomacrograph of the brain of the camel after separation of the two cerebral hemisphere (dorsolateral view) showing: (c) Cerebellum (c ca) Corpus callosum (h c) Hemispherium cerebella (c r) Colliculus rostralis (c c) Colliculus caudalis (s c) Splenium corporis callosi (g p) Glandula pinealis.

Light microscopic observations:-The camel pineal gland is surrounded by thick fibrous connective tissue capsule. It consists of collagen fibers and covered by pia mater, one layer of meninges. The septa divide the parenchyma into indistinct lobules (Fig.2 A). The pinealocytes and glia cells or interstitial (supporting) cells are the two types of parenchymal cells. This classification is according to shape, position and staining density. The number of pinealocytes exceeds the number of glia cells and they are present singly or in form of irregular cords or follicles. The pinealocytes were oval to round in shape, with lightly basophilic cytoplasm and eucromatic nuclei with prominent nucleoli. The glia cells are distributed in the interstitial tissue between the pinealocytes or around the perivascular spaces. These cells are small containing long processes with dark stained cytoplasm and dark elongated nuclei. Calcified concretions or brain sand are present in camel pineal gland. They were globular in shape which present inbetween the pinealocytes (Fig.2 B).The blood vessels surrounded by collagen fibers and perivascular space (Fig.3A\&B). Purple magenta colour staining with PAS was observed around the blood vessels (Fig.4A\&B).
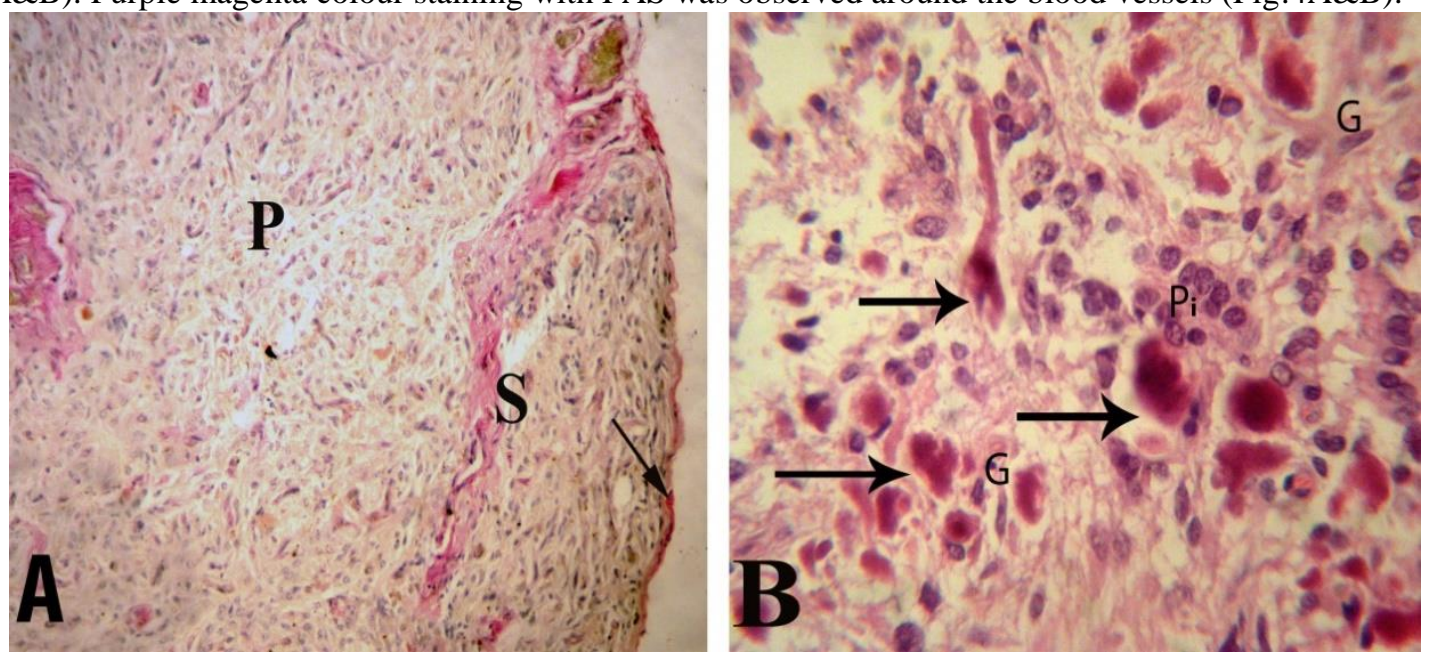

Fig 2:- Photomicrograph of pineal gland of camel showing the capsule (arrow) and septa (S) were formed from collage fibers and the parenchyma $(\mathrm{P})\{\mathrm{A}\}$. In $\{\mathrm{B}\}$, the parenchyma were consists of pinealocytes $(\mathrm{Pi})$, glia cells $(\mathrm{G})$ and brain sand (arrows). Stain: Van Gieson. x. 100 in $\{A\}$ and H\&E stain. $x 100$ in $\{B\}$. 

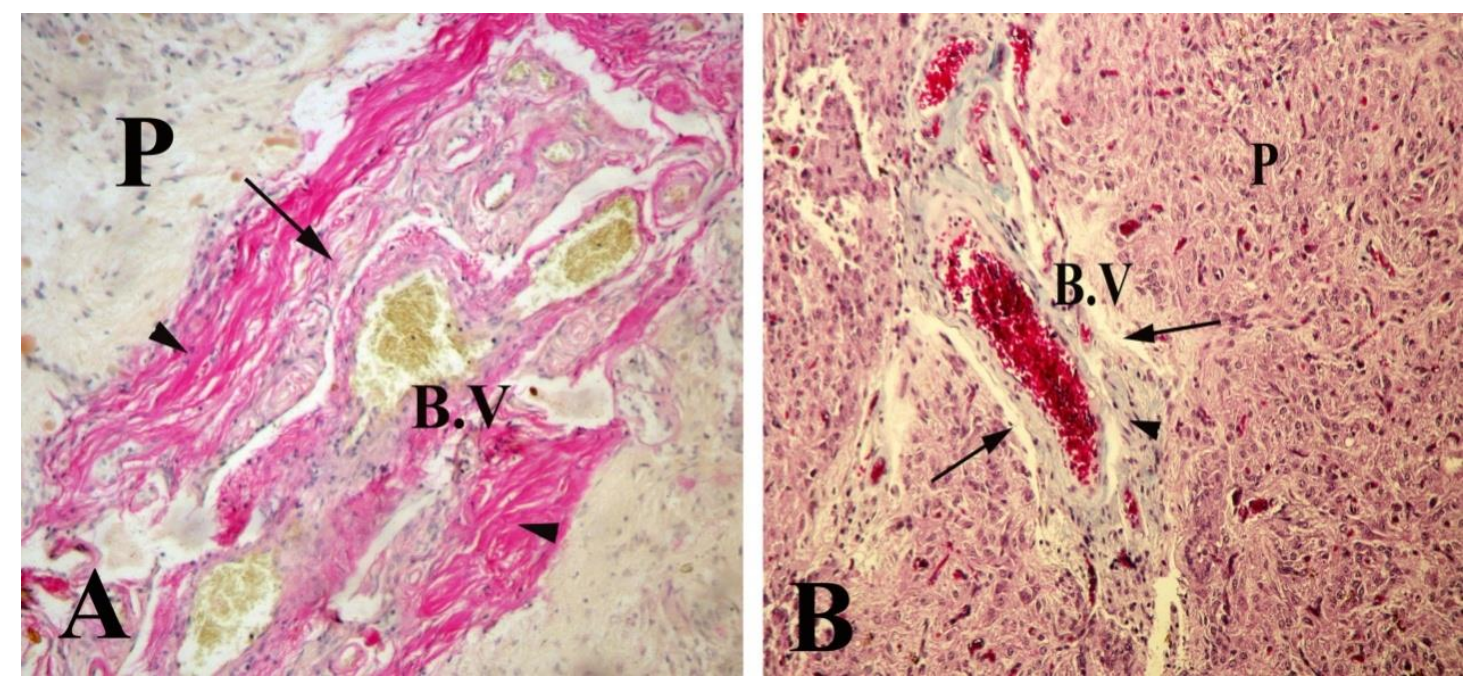

Fig 3:- Photomicrograph showing the parenchyma (P) of pineal gland contains blood vessel (B.V) surrounded by collagen fibers (arrow heads) and perivascular space (arrows). Stain:Van Gieson, x.400 in $\{\mathrm{A}\}$ and Crossmon trichrome. $\mathrm{x} .100$ in $\{\mathrm{B}\}$.
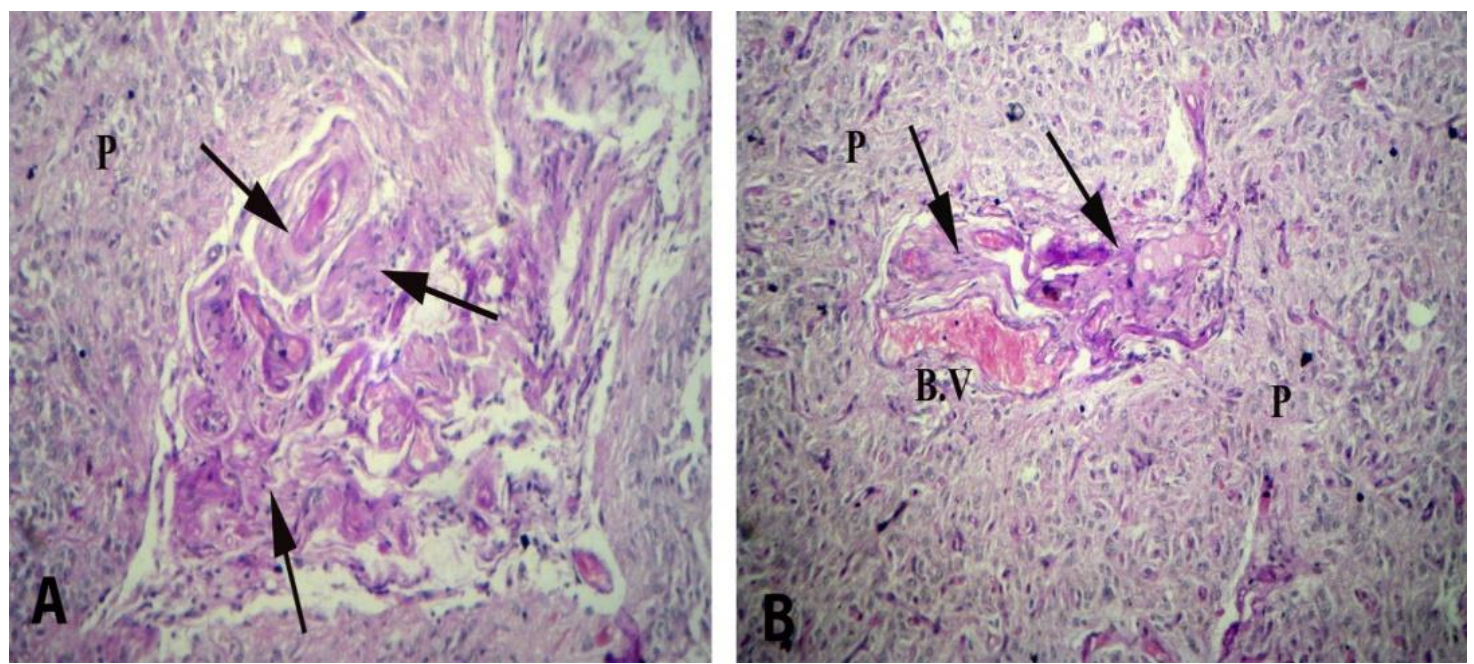

Fig 4:- Photomicrograph showing the parenchyma $(\mathrm{P})$ of pineal gland shows purple magenta colour staining with PAS (arrows) and blood vessel (B.V). Stain:PAS. x. 100 in $\{$ A $\}$ and $\{B\}$.

\section{Immunohistochemical examination:-}

Synaptophysin:-Immunoreactive cells were observed with strong reaction in the periphery of the gland and with moderate reaction in the other regions of the gland (Fig.5A). The reaction of pinealocytes to the synaptophysin immnoreactivity shows different degrees of density (Fig.5B). The reaction was mainly observed in the perivascular spaces (Fig.5C). The negative reaction was observed around the brain sand (Fig.5D). Small clear vesicles were observed, that were positive to the synaptophysin immunoreactivity (Fig.5E).The interstitial tissue shows negative reaction (Fig. 5F). 

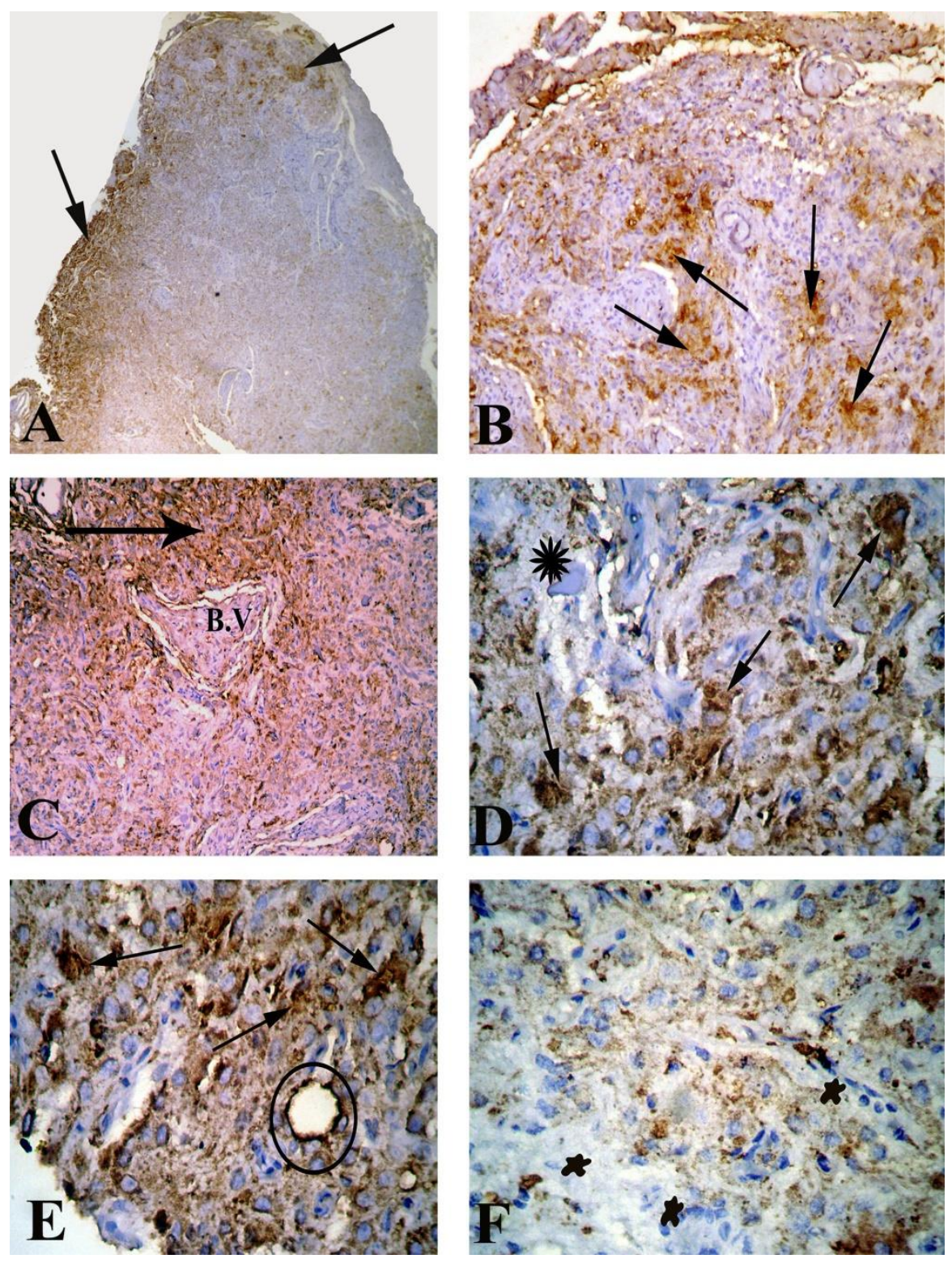

Fig 5:- Photomicrograph of pineal gland of camel showing the immunoreactivity of synaptophysin.

A: showing strong reaction in the periphery (arrows) of the gland and with moderate reaction in the other regions of the gland. B: The reaction shows different degrees of density (arrows). C: The reaction (arrow) was mainly observed in the perivascular spaces. D: The negative reaction (asterisk) was observed around the brain sand and positive reaction around the pinealocytes (arrows). E: Strong positive reaction (arrows) and small clear vesicles were observed (circle) that were positive to the synaptophysin immunoreactivity. F: the interstitial tissue gave negative reaction (stars). Immunoperoxidase staining. x. 100 in (A\&B), x.400 in (C-F)

Vimentin:-The positive reaction to vimentin immunoreactivity was distributed throughout the gland (Fig. 6A). It was observed with strong reaction in the capsule and septa of the gland (Fig. 6B). The glia cells with its processes were positively immunostained to vimentin in form of star shaped cells (Fig. 6C). The positive reaction was detected in the endothelial cells of blood vessels and around the perivascular spaces forming network while in in most region of the gland the reaction to vimentin was loose (Fig. 6C, D\&E). Vimentin-positive immunoreactivity was observed around the brain sand (Fig. 6F). 

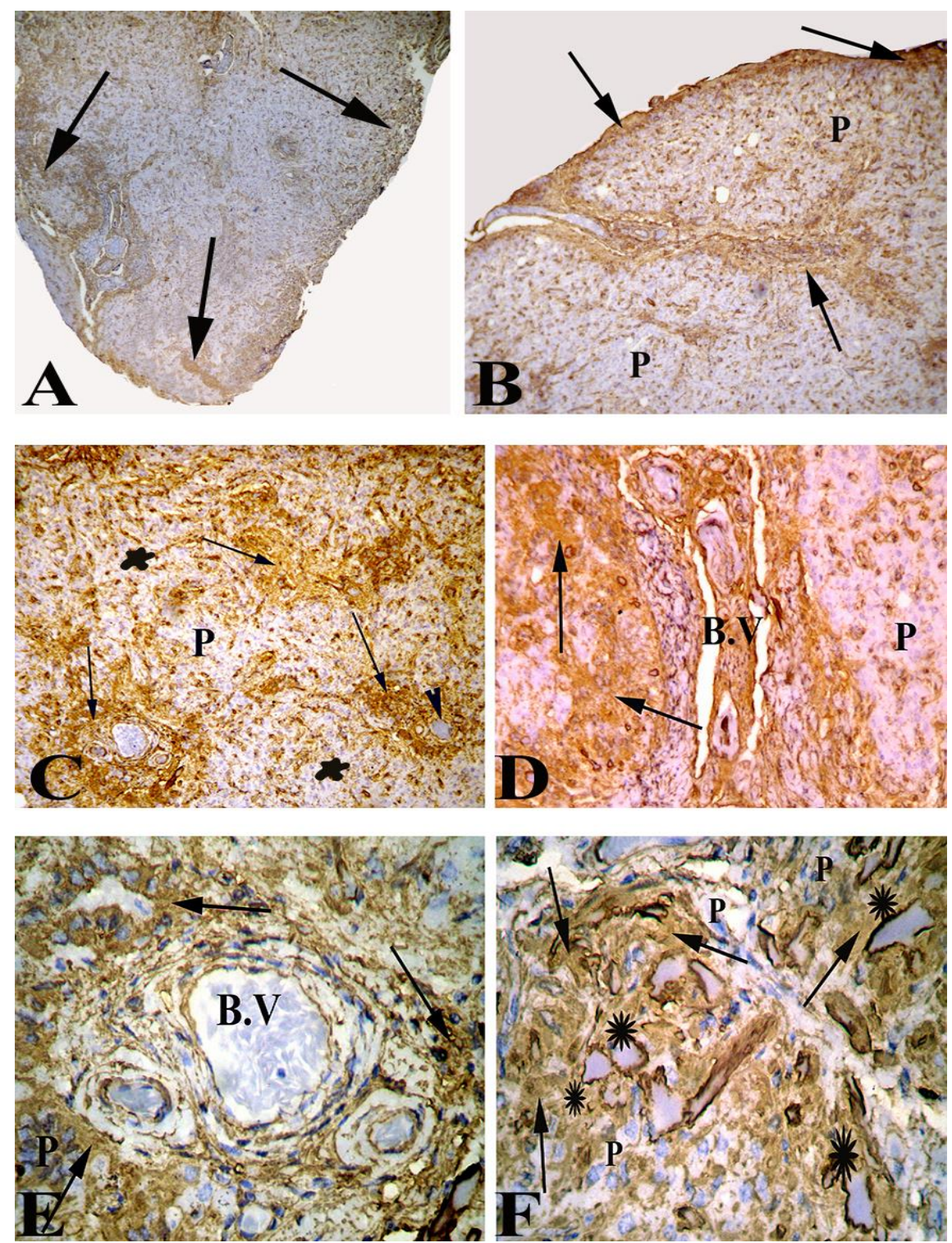

Fig 6:- Photomicrograph of pineal gland of camel showing the immunoreactivity of vimentin.

A: The positive reaction to vimentin immunoreactivity was distributed throughout the gland (arrows). B: Strong reaction in the capsule and septa (arrows) of the gland. C: The glia cells with its processes were positively immunostained to vimentin in form of star shaped cells (stars) and the strong reaction around the blood vessels forming network (arrows). D: The positive reaction around the perivascular spaces of blood vessels (B.V) forming network (arrows). E: The positive reaction (arrows) was detected in the endothelial cells of blood vessels (B.V).F: Vimentin-positive immunoreactivity (arrows) was observed around the brain sand (asterisks); (P) indicated the pinealocytes. Immunoperoxidase staining. x. 100 in (A\&B), x. 400 (C-F)

S-100 protein:-Immunohistochemical examination revealed that strong positive reaction was observed and distributed all over the gland especially in the stalk and the proximal region of the gland that was denser than vimentin immunoreactivity. The cytoplasmic processes forming network inbetween the pinealocytes (Fig. 7A).The reaction was detected also around the perivascular space and around the brain sand (Fig. 7B). 


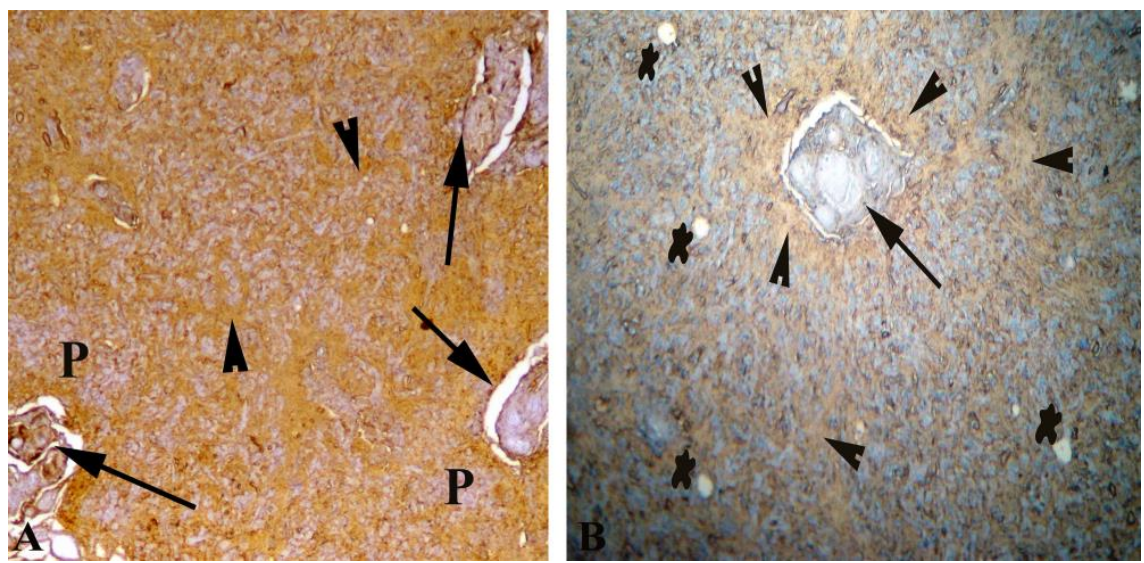

Fig 7:- Photomicrograph of pineal gland of camel showing the immunoreactivity of S-100. A: The positive reaction was observed and distribute all over the gland, the cytoplasmic processes forming network (arrow heads) inbetween the pinealocytes $(\mathrm{P})$, the perivascular spaces (arrows). B: The reaction (arrow heads) was detected around the perivascular space (arrow) and around the brain sand and small clear vesicles were observed (stars). Immunoperoxidase staining.x. 100 in (A), x. 400 in (B)

GFAP:-Immunoreactive cells were mainly distributed in the proximal region of the gland and little reaction in the distal region. The reaction showed the same characters and distribution to the S-100-reactive cells, but less dense. The strong positive reaction was observed around the perivascular spaces. The regions in which the pinealocytes form aggregations, the reaction was moderate (Fig. 8A, B,C).
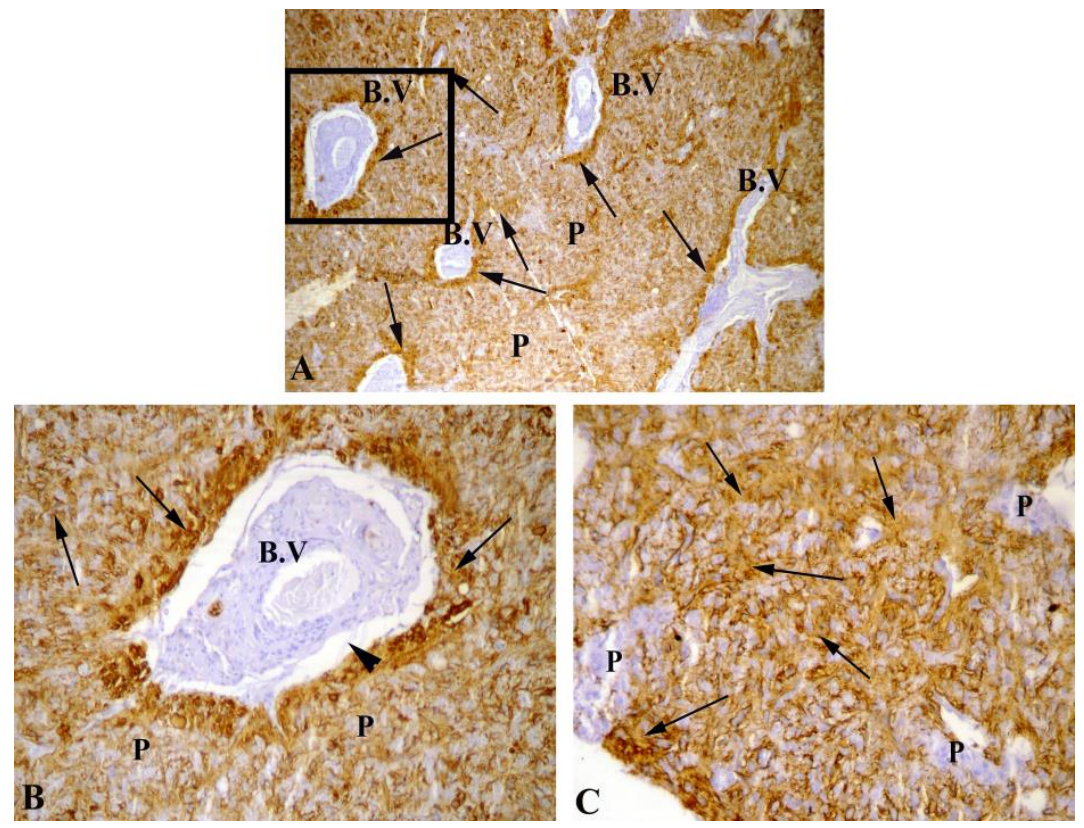

Fig. 8:- Photomicrograph of pineal gland of camel showing the immunoreactivity of GFAP. A: The strong positive reaction (arrows) was observed around the perivascular spaces of blood vessels (B.V), pinealocytes (P).B: A higher magnification of the rectangle in figure (A). C: The regions in which the pinealocytes $(\mathrm{P})$ form aggregations, the reaction was moderate. Immunoperoxidase staining.x.100 in (A\&c), x. 400 in (B).

\section{Discussion:-}

The shape of the gland was fusifrom and this finding was coincided with the statements of (Carvalho et al., 2009) in buffalo, (Ebada, 2012) in donkey. The location of the camel pineal gland in this study was similar to that described in other mammals, (Hendelman, 2000; Dyce et al., 2002, Frandson et al., 2007, Ebada, 2012 and Nawal et al., 2012). 
The pineal gland secretes melatonin, which has role on adjustment of sexual development, sleep-wake cycle, seasonal adaptation and ovulation in addition to its antioxidant activity (Uyar and Alan, 2008 and Pandi-Perumal et al., 2008). This hormone is produced by the pineal gland and by other organs such as gonads and involved in the regulation of the hypothalamic-pituitary-gonadal axis in photoperiodic species (El-Raey et al., 2011). Melatonin blocks the secretion of gonadotropins (luteinizing hormone and follicle stimulating hormone) from the anterior pituitary gland. These hormones are important for gonadal development and function (Lahmam et al., 2008).

The present study showed that, the camel pineal gland is surrounded by fibrous connective tissue capsule. The connective tissue septa divide the parenchyma into indistinct lobules. The pinealocytes and glia cells are the two types of parenchymal cells. This classification is according to shape, position and staining density. The pinealocytes were oval to round in shape, with lightly basophilic cytoplasm and eucromatic nuclei with prominent nucleoli. The glia cells are distributed in the interstitial space between the pinealocytes or around the perivascular spaces. These cells are small containing long processes with dark stained cytoplasm and dark elongated nuclei. This confirm the previous studies, (Junqueira and Carneiro, 2003), (Kus et al., 2004) in rat, (Gil et al., 2005) in the pregnant and non- pregnant vizcachas, (Castro and Munoz 2009), (Ebada, 2012) in donkey and (Nawal et al., 2012) in camel.

The present work revealed that, the pineal gland of camel contains brain sand, This was also mentioned by some authors in different mammalian species as dog (Abou-Easa, 1997 and Garma- Avina, 2000), buffalo (Lalitha and Seshadri, 1992), and camel (Abbas and Ewais, 1982 and Nawal et al., 2012), the pig (Lewczuk et al., 1994), but the concretions are extremely frequent in the gerbil (Krstic, 1986) and the human (Zimmerman and Bilaniuk, 1982).

In the human pineal, the brain sand arises from precipitation of calcium phosphates and carbonates on carrier proteins which released into the cytoplasm when the pineal secretions are released by exocytosis. They are present in childhood and increase in number with age. Corpora aranacea are in two locations that are intrapineal in the pineal parenchyma and extrapineal in the pineal capsule. (Koshy and Vettivel, 2001, and Urusopon et al., 2012).

In the present study, the brain sand is globular which present inbetween the pinealocytes. This was also mentioned by some authors (Koshy and Vettivel, 2001 and Urusopon et al., 2012). The forementioned authors added that there was another type which was a concentric lamellar type which seen around glial fibers.

The present study revealed that synaptophysin immunoreactive cells were observed with strong reaction in the periphery of the gland and with moderate reaction in the other regions of the gland. The reaction of pinealocytes to the synaptophysin immnoreactivity shows different degrees of density. These results are similar to the findings of some authors Redecker et al. (1990), Redondo et al. (2001) and (Ebada, 2012) in donkey. (Sato et al. 1995 and Feng et al. 1998) mentioned that the intercellular differences in the grades of synaptophysin immunostaining might, therefore, reflect different states of a specific cellular activity. The presence of synaptophysin in pinealocytes of the normal pineal, give emphasis to the paraneuronal character of these cells. The reaction was mainly observed in the perivascular spaces. This was similar to that described in other mammals, Redondo et al. (2003) in sheep and (Ebada, 2012) in donkey.

The negative reaction was observed around the brain sand and in the interstitial cells. Immunoractivity to synaptophysin was less dense in the brain sand, may be due to increases number of interstitial cells and tendency of pinealocyte to form island separated by aggregations of intersitial cells (Ebada, 2012).

The results of the present study showed that small clear vesicles were observed, that was positive to the synaptophysin immunoreactivity, this was similar to that described in other mammals( Ebada. 2012). The processes of pinealocytes, filled with accumulations of small clear vesicles, similar vesicles have a role in the secretory activity of the gland, and or in the transport of calcium (Redecker et al., 1990).

The observation revealed that the positive reaction to vimentin immunoreactivity was distributed throughout the gland. The positive reaction was detected in the endothelial cells of blood vessels and around the perivascular spaces forming network while in in most region of the gland the reaction to vimentin was loose. These results are similar to the findings of some authors (Suzuki and Kachi, 1995). 
The current study revealed that the presence of the three glial marker proteins (vimentin, S-100 and GFAP) has been shown in the neuroglia cells of the pineal gland. These results were proved by some authors (Yamamoto et al., 1990 and LOpez-Munoz et aI., 1992). Also the presence of GFAP and protein S-100 in interstitial cells in nonneoplastic pineal gland in human (Jouvet et al. 1994), in rat (Takada et al. 2006) and in donkey (Ebada, 2012).

In line with other previous studies, S100 immunoreactive cells showed similar morphological characteristics to those of GFAP-reactivity, but their immunoreactivity more dense than GFAP-positive cells, (Ebada, 2012) in donkey. While in rat, GFAP immunoreactive cells showed similar morphological characteristics to those of S-100-reactive cells in the stalk and the proximal region of the body portion of the pineal, but in the distal region of the body portion, GFAP-positive cells were not seen (Suzuki and Kachi 1995).

It can be concluded that there were differences between the proximal and distal region of the gland in the expression of glia marker protein.

\section{References:-}

1. Abbas, A.A. and Ewais, M. S. (1982): Histological and histochemical studies of the pineal gland of the one humped camel (Camelus dromedarius). Journal of Egyptian Veterinary Medical Association; 42 (2), 117-124

2. Abou-Easa, K. F. (1997) Tissue changes in the pineal retina and thymus of male dog before and after sexual maturity. Alexandria Journal of Veterinary Science 13 (4): 333-344.

3. Abou-Easa, K. F.; Tousson, E. and Abd- El-Gawad, M. (2009). Involution signs during the postnatal life in the pineal tissue of Buffalo and Camel. Nature and Science, 7(9): 35-44.

4. Arendt, J. (1995): Melatonin and the mammalian pineal gland. London: Chapman \& Hall; 1995. pp. 6-49

5. Bancroft, J. D and Gamble, M. (2001): Theory practice of histological techniques, 5th Ed. Churchill living stone.

6. Boya, J. and Calvo, J. L. (1993): Immunohistochemical study of the pineal astrocytes in the postnatal development of the cat and dog pineal gland. J Pineal Res 15: 13-20

7. Castro, A. E. and Munoz, E. M. (2009): Cell types in the adult rat pineal gland. Acta Microscopica, Vol. 18, Supp. C, 2009

8. Calhoun, M. E.; Jucker, M.; Martin L. J.; Thinakaran, G.; Price, D.L. and Mouton, P. R. (1996):"Comparative evaluation of synaptophysin-based methods for quantification of synapses". J. Neurocytol. 25 (12): 821-8.

9. Carvalho, A. F.; Ambrosio, C. E.; Miglino, M. A.; Mancanares, C. A. and Blazquez F. J. (2009): MacroMicroscopical aspects of the buffalo (Bubalis bubalis Linnaeus, 1758) pineal gland. Biotema, 22 (2): 127-135.

10. Dyce, K. M.; Sack, W. O. and Wensing, C. J. G. (2002): Textbook of veterinary anatomy.3rd Ed. Saunders. An Imprint of Elsivier Sci. Philadelphia, pp: 213.

11. Ebada, S. (2012): Morphological and Immunohistochemical Studies on the Pineal Gland of the Donkey (Equus asinus).J. Vet. Anat.Vol 5 No 1, $47-74$

12. El-Raey, M.; Geshi, M.; Somfai, T.; Kaneda, M.; Hirako, M.; Abdel-Ghaffar, A. E.; Sosa, G. A.; El-Roos, M. E. and Nagai, T.(2011):Evidence of melatonin synthesis in the cumulus oocyte complexes and its role in enhancing oocyte maturation in vitro in cattle. Mol. Reprod. Dev., 78(4):250-62

13. Feng, X. L.; Usui, H.; Fujita, T.; Ichikawa, T.; Katagiri, T.; Washiyama, K. and Ku-manishi, T. (1998): Postnatal development changes in NSE and NNE mRNA expression in the rat pineal gland: in situ hybridization histochemistry. J. Pineal Res., 24 (2), 108-116.

14. Frandson, R. D.; Lee Wilke, W. and Anna Dee Fails (2009): Anatomy and physiology of farm animals. $7^{\text {th }}$ Ed. Lea and febiger, Philadelphia.Pp 288-302.

15. Garma-Avina, A. (2000): Excretory plugs from the choroid plexus in the cerebrospinal fluid of dogs with neurological disease possible role in the formation of corpora arenacea. Journal of Comparative Pathology. 123(2-3), 146-151

16. Gil, E.; Calderón, C.; Pelzer, L.; Domínguez, S.; Fogal, T.; Scardapane, L. and Piezzi R.S. (2005): Morphological and biochemical study of the pineal gland of pregnant and non-pregnant female vizcachas (Lagostomus maximus maximus). NeuroEndocrinol Lett. Oct; 26(5):575-80.

17. Heizmann, C.W.; Fritz, G. and Schafer, B.W. (2002): S100 proteins: structure, functions and pathology. Front Biosci;7: d1356-68.

18. Hendelman, W. J. (2000): Atlas of functional neuroanatomy. CRC Press, New York, pp: 24.

19. Iqbal, A. (1999): Studies on some of the productive، reproductive and behavioral aspects of camel in Pakistan (PhD Dissertation). Deptt. Livestock Management. Univ. Agri., Faisalabad, Pakistan

20. Junqueira, L.C. and Carneiro, J. (2003): Basic histology: text \& atlas. 10th ed. USA: McGraw-Hill Companies; p. 430. 
21. Jouvet, A.; Fèvre-Montange, M.; Besançon, R.; Derrington, E.; Saint-Pierre, G.; Belin, M. F.; Pialat, J. and Lapras, C. (1994): Structural and ultrastructural characteristics of human pineal gland, and pineal parenchymal tumors. Acta Neuropathologica Vol.: 88, Is-sue: 4 : 334-348

22. Khan, B. B.; Iqbal, A. and Riaz, M. (2003): Production and Management of Camels. Pakistan. T. M. Printers, AlRahman Plaza, Aminpur Bazar, Faisalabad, Pakistan.

23. Kus, I.; Sarsilmaz, M.; Aslan O.; Ozdem, T.; Pekmez, H.; Songur, A. and Kelestimur, H. (2004): Light and electron microscopic examination of pineal gland in rats exposed to constant light and constant darkness. Neuroendocrinology Letters 25: 102-108.

24. Koshy, S. and Vettivel, S. K. (2001): Varying Appearances of Calcification in Human Pineal Gland: A Light Microscopic Study. Journal of Anatomical Society of India.; 50: 17-18

25. Krstic R. (1986): Pineal calcification: its mechanism and significance. J Neural Transm Suppl; 21:415-32.

26. Lahmam, M.; El M'rabet, A.; Ouarour, A.; Pévet, P.; Challet, E. and Vuillez, P. (2008): Daily behavioral rhythmicity and organization of the suprachiasmatic nuclei in the diurnal rodent, Lemniscomys barbarus. Chronobiol. Int., 25(6):882-904.

27. Lalitha, P.S. and Seshadri, V.K. (1992). Histology and histochemistry of degenerative changes in the pineal gland of adult Indian buffaloes (Bubalus bubalis). Indian Veterinary Journal. 69 (5): 427-430.

28. Lewczuk, B. ; Przybylska, B. and Wyrzykowski, Z. ( 1994): Distribution of calcified concretions and calcium ions in the pineal gland. Folia Histochem.Cytobiol; 32:243-9.

29. LOpez-Munoz, F.; Calvo, J.L,; Boya, J. and Carbonell , A.L .(1992): Coexpression of vimentin and glial fibrillary acidic protein in glial cells of the adult rat pineal gland. J Pineal Res 12: 145-148

30. Nawal, S.O.; Ismail, H.I. and Osman, D.I. (2012): Morphology of the pineal gland of the one humped camel (Camelus dromedarius). U of K. J. Vet. Med. \& Anim. Prod. Vol. 3, No 2, (65-81)

31. Nomina Anatomica Veterinaria (2012):5th edition, prepared by the International Committe on Veterinary Gross Anatomical Nomenclature (I.C.V.G.A.N.) and authorized by the General assembly of the World Association of Veterinary Anatomists (W.A.V.A.), konxville,T.N (USA). Published by the Editorial Committee, Hannover, Columbia, Gent and Sapporo. Pp 1-160.

32. Pandi-Perumal, S. R.; Trakht, I.; Srinivasan, V.; Spence, D. W.; Maestroni, G. J.; Zisapel, N. and Cardinali, D. P. (2008): Physiological effects of melatonin: role of melatonin receptors and signal transduction pathways. Prog. Neurobiol., 85(3):335-53

33. Polak, J. M., and Noorden, V. (1997): Introduction to immunocytochemistry. Second edition. BIOS, Scientific Publishers, Oxford, UK.

34. Redecker, P.; Grube, D. and Jahn, R. (1990): Immunohistochemical localization of synaptophysin (p38) in the pineal gland of Mongolian gerbil (Meriones unguiculatus). Anat. Em-bryol., 181 (5), 433-440

35. Redondo, E., A., Masot J, Fran co A. and Regodón S. (2001) :Immunohistochemical and ultrastructural characterization of pinealocytes in sheep prenatal development. Revue Méd.Vét., 2001, 152, 7, 535-544

36. Redondo, E.; Regodon, S.; Fran co, A.; Masot, J.; Gzquez, A.; and Cardinali, D. P. (2003): Day night changes in plasma melatonin levels, synaptophysin expression and ultrastructural properties of pinealocytes in developing female sheep under natural long and short photoperiods. Histol Histopathol. 18: 333-342

37. Sato, T.; Kaneko, M.; Ekataksin, W. and Wake, K. (1995): Expression of neuron-specific enolase in the pineal organ of the domestic fowl during post-hatching development. Cell Tissue Res., 279 (1), 25-36.

38. Shimizu, F.; Sanada, K. and Fukada, Y. (2003): Purification and immunohistochemical analysis of calcium-binding proteins expressed in the chick pineal gland. J. Pineal Res. 34, 208-216.

39. Suzuki, T. and Kachi, T. (1995):Immunohistochemical Studies on Supporting Cells in the Adrenal Medulla and Pineal Gland of Adult Rat, Especially on S-100 Protein, Glial Fibrillary Acidic Protein and Vimentin. ActaAnat Nippon $70: 130-139$.

40. Takada, Y.; Fariss, N.; Muller, M.; Bush, A.R.; Rushing, E. J.; Sieving A. (2006): Retinoschisin expression and localization in rodent and human pineal and consequences of mouse RS1 gene knockout. Mol Vision 12: 1108-1116

41. Urusopon, K.; Pornkunnatham, U.; Roongruangchai, J.; Sripaoraya, K. and Viravud, Y. (2012): The Histology of the Pineal Gland in Cadaveric Embalmed Specimens). Siriraj Med J; 64 (Suppl 1): S54-S57. E-journal: http://www.sirirajmedj.com

42. Uyar, A. and Alan, M. (2008): Koyunlarda erken anostrus doneminde melatonin uygulamalarinin ovulasyon ve gebe likuzerine etkisi.Yyu. Vet. Fak. Derg., 19(1):47-54.

43. Vigh, B.; Szel, A.; Debreceni, K.; Fejer, Z.; Manzano, M. J. and Vigh-Teichmann, I. (1998): Comparative histology of pineal calcification. Histological Histopathology. 13(3)851-870

44. Yamamoto, M.; Kondo, H; Yamakuni, T. and Takahashi, Y. (1990): Expression of immunoreactivity for Cabinding protein spot 35 in the interstitial cells of the rat pineal organ. Histochem J22: 4-10

45. Zimmerman, R.A. and Bilaniuk, L.T. (1982): Age related incidence of pineal calcification detected by computed tomography. Radiology,659: 61-142. 